\title{
BENOIT, HECTOR. A ODISSEIA DE PLATÃO: AS AVENTURAS E DESVENTURAS DA DIALÉTICA. SÃo PAULO: ANNABLUME, 2017. 564 P. ISBN 978-85-391-0872-5.
}

Fernando Dillenburg ${ }^{1}$

\section{Keywords}

\section{Plato; dialectic; Hector Benoit}

"Plato's odyssey: fortunes and misfortunes of dialectic", by Hector Benoit, published by Annablume, 2017, represents a true revolution to the interpretation of the Dialogues. According to Benoit's exposition, it is possible to get to know another Plato, much different from the one presented by the tradition. Here lies the revolutionary force of this work. In the predominant tradition, as we know, Plato is identified to Socrates. Benoit proves, starting from what the author wrote in the Dialogues ${ }^{2}$, that Socrates is almost permanently facing aporias and is even mocked at by various characters in the different dialogues.

The first and deeper aporia of Socrates is the one risen by the famous philosopher from Elea, Parmenides, in the homonymous dialogue, which takes place, in the lexis temporality, around 400 B.C. There, Parmenides, already an old man, doubts about the recently formulated theory of the Socratic ideas, asking to the (still) young Socrates if he agreed that the ideas were pure, exempt of any contradiction. Receiving an affirmative answer from the young man, Parmenides questions how Socrates would establish the relation between the ideas and the sensible world, without contaminating them with the contradictions of multi-

\footnotetext{
1 Assistant Professor, Federal University of Rio Grande do Sul, Porto Alegre, Brazil. E-mail: ffrotadillenburg@gmail.com

2 In another work Bemoit exposes the method he created, called by Arley Moreno "the immanentistic method". According to this method, the interpretation of a philosophical work should start at the temporality of the lexis ("the act of saying"), or even the method of exposition that is objectively and literally linked to the actual text of the author. From the temporality of the lexis on can reach, in first place, the logico-conceptual temporality, the temporality of the noesis ("the act of thinking"). After getting to the noesis (starting from the lexis), we reach the temporality of the genesis (the historical era per se, the conceptual history of a knowledge and, also, the individual, biographical history of the author). From this historical and biographical temporality (genesis) we can finally reach the temporality of poiesis, the act of producing a work, the time for producing a work, the chronology of this work. Cf. BENOIT, H. Plato and the temporalities: the methodology question. São Paulo: Annablume, 2015.
} 
ple sensible existing beings. Socrates cannot find an answer to the problem Parmenides presented, which is the difficulty to establish a relation between ideas and sensitive beings, i.e. to put the ideas in practice, to find a link between science and every day life of people. Because of this, Socrates remains silent for almost 15 years. Socrates understands that the bigger difficulty was not in giving to the ideas the role of basis of sensible things, but to secure the relation between the two levels, the level of ideas or intelligible sphere and the level of images and objects, plants and animals that make the sensible sphere.

Even after restarting philosophy after 15 years of silence (around 434 B.C.), helped by two mystic resources, Delphos's oracle and the power of Eros, Socrates will be tormented by Parmenides's question to the end of his life. This happens, for example, in the Symposium dialogue, circa 416

B.C. There Socrates, already 54 , is criticized by his old favorite ex- disciple, Alcibiades (already a political leader in Athens), who describes him, in front of all, as a mere young people seducer, who cunningly used his lovers' souls for self-knowledge, without ever surrender his own soul to his passionate partners. In his speech, Alcibiades, now a politician of Athens and no more the young person of Alcibiades I, is saying that Socrates never engendered to his disciples' beautiful ideas, beautiful actions in order to form beautiful souls. The absence of reflexibility of Socrates' soul could mean that his knowledge was not-transferable, merely subjective, only achieved by himself and impossible to be followed. Even more, the attitude of the intemperate Alcibiades, who arrived suddenly, drunk, followed by flute players, bacchantes, to the Symposium offered by the poet Agathon, would be a strong symbol of Socrates's incapacity to form disciples able to follow his personal apparent moral rectitude, showed in various dialogues.

Eight years after the Symposium, Socrates faces new aporias in the Republic. In this dialogue, dated circa 408 B.C., Socrates traces the last level of the reign of ideas, the supreme level of knowledge, which he calls the Good, a region beyond ousia, way beyond the essence of sensible beings. If the Good were really beyond the essence, it would remain far beyond the reach of human reason, so transcendent that would probably be beyond human knowledge, only attainable by gods.

But, according to Benoit, it is not Plato who defends this transcendence of the Good, but Socrates. Benoit understands it by following Plato's lexis. It is so possible to see, in the Republic dialogue, the doubtful figure of Socrates, who, by elevating the Good beyond any essence, gets the ironic comments of Glauco, Plato's brother. So, Glauco says: "by Apollo! What a wonderful transcendence!". Benoit observes that this ironic comment of Glauco's cannot be under 
esteemed, on the contrary, it represents a symbol of the criticism to the metaphysic defended by Socrates, a way based on an assumption so transcendent that it would be unattainable by humans. The predominant tradition, on the contrary to Benoit's ideas, assigns to Plato this theory, based on the absolute transcendence of the Good, making him, instead of the annihilator of the Socratic metaphysic, the founder of this exact metaphysic. As we see, Plato is presented by Benoit in a totally polemic way, different from the traditional Plato: instead of father of the theory of ideas, advocate of the absolute transcendence of the Good, founder of the occidental metaphysic, Plato is showed by Benoit as the first big critic of the idealistic and metaphysic perspective, that Socrates was unable to overcome.

Let's follow the reading of the Plato's Odyssey, which is more like a philosophical novel, totally accessible by non-specialized to Plato readers or even non-philosophers, without losing the deepness of a philosophical work.

Still in the Republic dialogue, the absolute transcendence of the Good represents a theoretical basis of the Socratic political project, imagining a city, ruled by a philosopher king, surrounded by guardians, all living in a special regime, where there wouldn't be any private property, with the community of women and children, all receiving a special education. The rest of the population of the city, the ones taking care of the work and the commerce, would not participate to this cast of guardians, and so the city would have different segments. It is evident that just the segment or cast of guardians, and not all the demos would have access to the political power and all the main decisions of the polis. This authoritarian political project of Socrates, where even the poets should be kicked out of the city, is also traditionally attributed to Plato. However, reading Plato through Benoit, this thesis appears, once again, totally arbitrary.

We can easily understand that by observing the information in the Dialogues themselves and what Benoit perfectly noted, which leads us to the Critias dialogue, that took place the day after the Republic dialogue. There, Critias, one the characters to whom Socrates narrates the Republic, compares the project of the Republic to a proto-historic Athenian civilization, that existed in a remote past, next to a big empire, called Atlantis. In this case also appear the casts like in the Republic, as well as a series of elements like those of the city projected by Socrates, the community of the women and children, etc. ${ }^{3}$

\footnotetext{
${ }^{3}$ Curiously enough, at the end of the XIX century, archeologists found out that it really existed a similar civilization in Greece in the past, a so-called "cretan-mycenaean" civilization, where existed monumental works, palaces and probably casts. This way, Critias would be recalling, through manuscripts brought from Egyptian temples by Solon, his ancestor, a civilization that really existed in the Greek remote past, a cretan-mycenaean civilization.
} 
Critias admires the authoritarian project of the Republic wishing to be able to execute it in the present. Strange enough, Critias seems to have historically, really attempted to execute that project, when, in 404 B.C., he took the power in Athens establishing the regime of the "Thirty tyrants", which was a total catastrophe, being overthrown in a few months. So, the Republic, instead of being the idealistic theory of Plato, would provoke doubts about the Socratic project of city, and all the failures and crimes committed by Critias, Socrates's disciple. Instead of being a project of the future, the Socratic project of city would be an absurd project of return to the proto-historic society of the Greeks. How could one defend a city divided between those who take decisions, the guardians commanded by a philosopher king and those who live an alienated life, feeding the "pure" warriors? How could one accept such different levels of life between the philosopher king and his guardians on one side and the rest of the demos? Really, in this Socratic project only the guardians and the philosopher king would live without the limitations of the private propriety, the goods would be common only for them, while most of the demos would be subjected to the antagonisms, the shortcomings and the threat of misery caused by the private appropriation. So, the reference of Critias to the proto-historic time of Athens and his own historical acts in 404-403 B.C. would clearly show the limitations of the Socratic project of a city.

As we can see, the shortcomings of the Socratic philosophy appear more and more in the dialogues. Another example can be found in the dialogue Theaetetus, occurring in 399 B.C., just before Socrates's death. In this dialogue, however, there is not a character who criticizes Socrates, but, surprisingly enough, Socrates himself. This attitude follows the one of Socrates refusing Theaetetus's suggestion to confront Parmenides. Socrates refuses this challenge, affirming: "Parmenides inspires me (....) respect and shame at the same time (...). I fear not understanding his words and so totally miss the deepest meaning of his ideas." This means that after 50 years from his encounter with Parmenides (from 450 B.C. to 399 B.C.), Socrates has still not the guts to confront him. And he admits: "Terrible, oh Teaetetus, really terrible and hateful to be a charlatan". Benoit, being literal to the lexis, observes that Teaetetus did not understand very well to whom Socrates was referring to, for this self- accusation was too surprising, and Socrates is forced to explain: "It is shameful for me to understand my own real charlatanism". Benoit questions then if Socrates was admitting that whoever was not confronting Parmenides was a mere charlatan. Let's follow the development of Plato's Odyssey.

The same day of the Teaetetus's dialogue, in 399 B.C., there is another fatal stroke for Socrates. The Teaetetus's dialogue ends when Socrates asks permission to go to the king's gantry in order to know what the accusation was the city had against him, in the Apology he is judged and sentenced to death as a 
corruptor of young people and a sophist. But, before that, there is the Sophist dialogue. Here appears the Stranger from Elea who is going to confront the "father" Parmenides, which means give existence to the non-existence, follow the way of denial, the way of the contradiction, the prohibited way in the whole western philosophy, the supreme way of the supreme dialectic, the way Socrates had never the guts to follow: the breach, at least relative, of the identity.

But, as if those misfortunes were not enough for the master Socrates, they do not stop, not even in Phaedo, his last dialogue, before taking the hemlock. During his last conversation with his more loyal disciples, in prison, Socrates asks them not to be sad, because, despite the death of his body, his soul will remain alive. Simias and Cebes, however, resist to his arguments, which means that, hours before his death, the old Socrates still has difficulty to make coincide his pure ideas of intelligible level with the ones of his counterparts who remain in the sensible level. Socrates, in his last moments, was still confirming Parmenides's thesis based on the impossibility of coincidence between ideas and sensible beings. Even his more loyal disciples, when the time of the death arrives, the time to drink the hemlock, break into tears. Socrates tells them that, unfortunately, they don't believe to the immortality of the soul. They stop crying, but, it seems, only out of respect for their master.

If the thinking of Socrates does not coincide with that of Plato, it is worth asking if there would be another character in the Dialogues who would have this role. According to Benoit, in the Laws dialogue, last dialogue in the temporality of the lexis and the only one where Socrates does not appear, because it happens many years after his death, there is a character who, significantly, is called the old Athenian, which coincides with Plato's age and origin. In this dialogue, three anonymous characters, of old age, walk on a road in Crete island. One of them is Cretan, the other Spartan and the third is exactly the old Athenian. Benoit supposes, as Cicero also did, that this Athenian could be a character very close to Plato, once the philosopher was near the end of his life, of his dialectical fortunes and misfortunes.

Representing or not Plato, one thing is undoubtful. The old Athenian of the Laws is superior to Socrates in many ways. Instead of a government of the philosopher king, surrounded by guardians, the Athenian proposes a government of councils, where each one of the parts of the polis, including the one of the armies, would choose, in an assembly, by rising their hands, their archons or commanders. Another difference between Socrates's ideas and those of the Laws was that the goods would be common to all the philoi, those who live together in the same community, which, in the city projected by Socrates, was exclusive to the privileged guardians. Another difference is that, instead 
of the moral rectitude almost impossible to follow and the expulsion of the poets from the city projected by Socrates, in the Laws, the art was considered a privileged moment in the education process and the parties, where also it was admitted the use of alcohol by the older than 18 years, in order to stimulate creativity. In the Laws, it was only possible to know oneself by remembering the history of the city (Aletheia), being this a social process, having the participation of the whole demos, the city celebrating, the supreme moment of the dialectic. Socrates, on the contrary, using the sophists' way, was searching the self-knowledge through private activities, non-public, like, for example, in the relation with Alcibiades.

Last but not least difference between the two projects of the city, is the possibility or not to be actually performed. For Socrates, this city "could exist perhaps in heaven", while in the Laws, the old Athenian proposes a transitory process for the city to be built. Imagining a possible resistance to the original project by people of the city, the old Athenian suggests that the legislators could momentarily leave it aside but doing all the effort in order to try to perform whatever seems more appropriate of it.

In conclusion, the project of the city contained in the Laws would be a project of the future, a project able to overpass the social inequalities of the Greek society of slavery, much superior to the Socrates's one, and at the same time nostalgic and utopic. And what does the predominant western tradition? It considers Plato the author of the project of the Republic. What would be the purpose for that? Probably, the non-revealed purpose would be to hide this dangerous Plato, the Plato of the Laws, the Plato defender of a community (koinonia) of the future, the city without social classes or casts, a direct democracy in an assembly, which elects by rising hands. The purpose of the predominant tradition is to maintain the status quo, this Plato of the Laws must stay occult, as much as possible, behind the supposed Plato of the Republic. But those whose purpose is not to maintain the society of classes will certainly find, in Plato's Odyssey, a great source of creative inspiration left by Plato and brought to light by this book of Benoit. Welcome Plato's Odyssey! May it be read many, many times over. 